DOI: 10.34015/2523-4552.2021.2.11

УДК 340.15:343.26

Сокальська О. В., кандидат юридичних наук, дощент e-mail:co2001@ukr.net

ORCID: 0000-0001-8737-0829

\title{
ПЕРШІ ПЕНІТЕНЦІАРНІ БУДИНКИ В ЄВРОПІ: ВІД РЕЛІГІЙНОГО БЛАГОДІЙНИЦТВА ДО СКЛАДОВОЇ КРИМІНАЛЬНОЇ ПОЛІТИКИ
}

У статті розглянуто процес становлення пенітенціарних установ, починаючи від формування в XVII ст. виправно-покаяльних карних закладів для священнослужителів і благодійних інституцій для утримання неповносправних делінквентів, що іменувалися пенітенціарними будинками, до нормативного закріплення 1779 р. «пенітенціарного експерименту» у Великій Британії та його реалізації, спершу у графствах, зокрема 1791 р. у Глостері, а на початку XIX ст. на загальнодержавному рівні. Визначено, коли й за яких умов терміни «пенітенціарний будинок» та «пенітенціарна система» утвердилися в англосаксонській пенальній термінології. Проаналізовано основні аспекти фундації та діяльності пенітенціарного будинку в Глостері та першого загальнонаціонального пенітенціарію Міллбенк, нормативні приписи та режимні засади функціонування.

Ключові слова: пенітенціарний будинок Корнето; Пенітенціарний акт 1779 р.; транспортація; каторжні роботи; пенітенціарний будинок в Глостері; пенітенціарна система; Головний пенітенціарій у Міллбенк.

В статье рассмотрен процесс становления пенитенциарных учреждений, начиная от формирования в XVII в. исправительно-покаянных заведений для отбывания наказания в изоляции священнослужителей, а также благотворительных учреждений для содержания неполноправных делинквентов, именовавшиеся пенитенциарными домами, к нормативному закреплению в 1779 г. «пенитенциарного эксперимента» в Великобритании и его реализации, сначала в графствах, в частности 1791 в Глостере, а в начале XIX в. на общегосударственном уровне. Определено, когда и при каких обстоятельствах термины «пенитенциарные дома» и «пенитенциарная система» утвердились в англосаксонской пенальной терминологии. Проанализированы основные аспекты основания и деятельности пенитенциарного дома в Глостере и первого общенационального пенитенциария Миллбенк, нормативные предписания и режимные принципы их функционирования.

Ключевые слова: пенитенциарный дом Корнето; Пенитенциарный акт 1779 г.; транспортация; каторжные работы; пенитенциарный дом в Глостере; пенитенциарная система; пенитенциарий Миллбенк. 
Постановка проблеми. Реформістський підхід до пояснення витоків модерної тюрми, що панував упродовж XIX ст., а саме твердження, що пенітенціарні системи постали виключно у наслідок гуманістичного прогресивного руху заміни тілесних покарань i смертної кари добре влаштованими в'язницями, у XX ст. зазнав суттєвої критики. Так, англійський поет i публіцист Дж. Айвс звинуватив філантропів XVIII ст. у жахливому експерименті над живими істотами, створенні «машини для спричинення страждань», у порівнянні $з$ якою, середньовічні варварства були нетривалими й відносно милосердними [1, 171]. У поясненні причин тюремних реформ дослідники, зокрема неомарксисти, уперше вийшли «за стіни тюрми» [2, 154], наголошуючи на соціально-економічних передумовах трансформації системи покарань, зумовлених формуванням капіталістичних відносин і політикою меркантилізму [3; 4].

У 60-70-х роках ХХ ст. теза, що тюремна реформа - це перманентний шлях до покращення умов ув'язнення переглянута авторами-ревізіоністами: Д. Ротманом, М. Ігнатьєвим та М. Фуко. Акцентуючи увагу на репресивних функціях пенітенціарних закладів і бажанні реформаторів контролювати делінквентів, вони створили дзеркальну модель того, що критикували [5, 2]. Підходи реформістів і ревізіоністів різнилися лише у тому, чи зміни були викликані гуманістичними, чи авторитарними мотивами. Обидва табори представляли пенітенціарну систему як результат різкого переходу від неефективних публічних кар до, у першому випадку, «гуманної тюрми», у друго- му - інститутів ефективного контролю і перманентного нагляду $[6,172]$. Їхні висновки грунтувалися на досвіді тюремних перетворень переважно у межах однієї держави, відповідно США, Британії чи Франції, без урахування загальноєвропейського тюремного дискурсу.

Однак на практиці тюремні інституції зазнавали суттєвої видозміни, по мірі того як первинні європейські чи американські пенітенціарні моделі переосмислювалися і розповсюджувалися по всьому світу $[7,3]$. Також їхні дослідження були зосереджені в межах традиційної хронології: кінець XVIII - середина XIX ст., що авторами-ревізіоністами було визнано періодом «народження модерної тюрми». Цей підхід нині переглянуто, зокрема у працях П. Шпіренберга, Н. Деві, Г. Гелтнера, М. Гібсон. Те, що раніше здавалося простим і відносно стрімким переходом від тілесних кар до модерної практики виправлення та реабілітації злочинців, сучасними дослідниками розглядається як більш складний і багатовекторний процес. Переосмислено не лише традиційні підходи до періодизації, але й мотиви трансформації стратегій покарання [5; 7]. Так, зокрема, на думку Дж. Вілліса визначальним для формування пенітенціарних систем у XIX ст. став процес формування державного апарату, у тому числі й у сфері управління кримінальновиконавчою сферою, і демократизація суспільства [6].

Отже, сучасна історіографія процес інституціалізації модерної тюрми розглядає як багатоступеневий у загальноєвропейському контексті, наполягаючи, що зміни відбувалися у результаті взаємодії ба- 
гатьох складових, будучи фазами у довготривалому розвитку. Відповідно до цього, мета статті - проаналізувати етапи становлення пенітенціарних установ у широких хронологічних і географічних межах: від формування в Італії у XVII ст. виправно-покаяльних та благодійних закладів до нормативного закріплення та реалізації «пенітенціарного експерименту» у Великій Британії та започаткування пенітенціарної системи.

Аналіз останніх досліджень i публікацій. Проблема зародження пенітенціарних установ в Європі та нормативних засад діяльності розглядалася переважно у межах національних в'язничних систем (М. Ігнатьєв, Ш. Мак-Конвіл, Л. Тронес [8; 9; 10]), або ж розвідки дослідників стосувалися окремих пенітенціарних будинків [11; 12$]$.

Виклад основного матеріалу. Формування спеціальних закладів для утримання делінквентів, відмінних від традиційних в'язниць (bridewells в Англії, tuchthuizen в Голландії та Німеччині) припадає на другу половину XVI ст. - початок XVII ст. Ув'язнення у них, 3 обов'язковою примусовою працею, носило характер, так би мовити, «внутрішнього вигнання» і застосовувалося як до злочинців за вироком суду, так і до асоціальних елементів як адміністративний засіб. Якщо у Голландії та німецьких землях це відбувалося в умовах секуляризації соціальної опіки й призвело до формування мережі в'язничних робітних будинків, підконтрольних магістратам, то в католицьких державах, боротьба з маргіналізацію поєднувала традиційні форми християнського благодійництва й новації соціальної опіки з боку муніципальної влади. Під егідою церкви в Італії організовано будинки покаяння (casa della penitenza) [13, 359; 14], де утримувалися асоціальні елементи, переважно повії та неповнолітні. Щодо них церква повернулася до античного концепту emendatio - не кари, а терапевтичного впливу на неповносправних. Такими, що володіють обмеженою правоздатністю, і заслуговують на пом'якшення покарання, у XVII ст. вважалися діти й жінки.

Починаючи 3 XVII ст., католицька церква не лише виконувала традиційні функції опіки засуджених і контролю за місцями ув'язнення, але й на доктринальному рівні сформувала нові підходи до покарання, «пронизаного християнським духом, невідворотного, але милосердного» $[15,451]$. Щодо його мети, принаймні в теорії, каральність відходила на другий план, поступаючись місцем покаянню та виправленню.

3 ініціативи Папи Урбана VIII 1627 р. як альтернатива галерам для священнослужителів та монахів, що вчинили злочини, в Корнето започатковано спеціальний карний заклад пенітенціарний будинок (Casa di Penitenza) [11]. Назва відбивала основну мету утримання (крім власне ізоляції) - перевиховання та покаяння, що мало досягатися не насильницькими методами, а милосердям, духовними практиками, бесідами 3 наставником, напучуваннями, ну i звісно, молитвами. У режимі пенітенціарного будинку реанімовано принципи середньовічного монастирського покаяльного ув'язнення. Ззовні заклад у Корнето нагадував палац, а всередині - монастир з рядами одиночних камер-келій і каплицею на 
торці. Але за задумом, це мала бути саме в'язниця з досить суворою системою нагляду та охорони. Двері та брами обов'язково б замикалися, щомісяця слід було переводити засуджених в інші камери, які щоденно перевірялися адміністрацією.

Новація пенітенціарного будинку в Корнето полягала не лише в тому, що він призначався для відбування покарання у виді позбавлення волі 3 метою покаяння та виправлення, що робить його одним із прототипів пенітенціаріїв XIX ст. Це ще й була перша тюрма 3 камерним одиночним режимом утримання та розділенням на ніч. Засуджені не оплачували утримання в пенітенціарному будинку та не повинні були працювати. Заклад фінансувався релігійними конгрегаціями, а його діяльність регламентувалася правилами, ухваленими 1674 р. [11].

За пенітенціарним будинком закріпилася назва Ергастоло (Ergastolo) [11, 18-19]. Цей термін в канонічній доктрині втратив початкове античне значення (місця ув'язнення рабів з обов'язковою примусовою працею) й позначав келію чи місце перебування монахавідлюдника для молитов та єднання з Богом [16]. Таким чином, утримання в ergastulum (ergastolo) - ізоляція не як покарання, а як найвища форма християнського аскетичного життя.

Отже, першим виправним закладом в Італії, де особлива увага приділялася суворому режиму й духовному переродженню через молитви, був саме пенітенціарний будинок у Корнето. Роздуми про тюрми монарших орденів Ж. Мабільйона лише розвинули ті ідеї, що лягли в основу його діяльності. А під час фундації виправної тюрми для непо- внолітніх Св. Михайла у Римі запозичено не лише архітектурнопросторовий устрій пенітенціарного будинку, але й окремі режимні засади [11, 28-29].

У другій половині XVIII ст. занепад покарання у виді галер зумовив потребу в організації карних закладів 3 обов'язковою примусовою працею, але уже для широкого коло правопорушників, а не лише неповносправних. Фактично, такі тюремно-виробничі комплекси у Мілані, Генті, Вілворді з чітким розділенням засуджених за категоріями, сегрегацією в одиночних камерах у ночі, спільними роботами в майстернях під наглядом i, як правило, у повному мовчанні, стали прототипами майбутніх пенітенціарних будинків. Однак, постає питання як назва італійських, досить нечисленних благодійних та релігійно-карних закладів - «пенітенціарні будинки» утвердилась в європейській пенальній термінології? Оскільки, ні щодо італійських виправних тюрем, ні щодо закладів у Північно-Західній Європі її не вживали: в Італії - це були casa di correzione, у Фландрії maison de force, у Голландії та Німеччині - spinhuis та tuchthuizen. Не зустрі-чаємо іiі i в роботі знаного англійського тюремного реформатора Дж. Го-варда. Натомість саме Британії належить першість не лише нормативного закріплення цієї назви для тюрем нового типу, але й утвердження терміну «пенітенціарна система».

У кінці 70-х років XVIII ст. у Британії при розробці проєкту заміни транспортації примусовими роботами у спеціальних каторжних тюрма, організованих на засадах суворої дисципліни у поєднанні з релігійним 
впливом, один 3 авторів законопроєкту, авторитетний англійський правник В.Блекстон запропонував змінити назву з «будинків каторжної праці» (houses of hard labour) на «пенітенціарні будинки» (penitentiary houses). В. Блекстон обирав між назвами «Ергастоло» і «пенітенціарний будинок» $[10,148-150 ; 17 ; 18$, 140]. У цьому вбачаємо певну наступність нових англійських місць відбування покарання та покаяльновиправної традиції, започаткованої в італійських закладах, зокрема в'язниці в Корнето, де вказані назви використовувалися паралельно. У підсумку перевагу надано терміну більш звичному, уживаному в англіканських релігійних практиках, а не латинському «ergastulum», що лише додавав асоціацій 3 працею невільників (депутати й так закидали авторам проєкту, що вони намагаються відродити рабство на «Острові свободи» $[10,116-117])$.

Таким перейменуванням

В. Блекстон намагався звернути увагу депутатів парламенту на те, що у нових закладах засуджені, як сподівалися фундатори, будуть змінюватися (ставати кращими) [17, 429]. I справа не в назві, а в ідеології, яку несли в собі пенітенціарні будинки: вони мали кардинально відрізнятися від існуючих місць ув'язнення, мета їх діяльності не лише кара та превенція, але й виправлення злочинця через каяття. Необхідність виправного впливу у нових каторжних тюрмах була зумовлена тим, що у разі скасування транспортації запеклі злочинці, які раніше висилались за океан (а це близько 1000 осіб щороку), залишалися б у країні й через якийсь час поверталися у суспільство [19, 116]. I депутати вкрай скептично ставилися до такої перспективи. Єдине, що могло їх переконати, так це те, що за період ув'язнення завдяки режиму, релігійному впливу й дисципліні вдасться перетворити колишніх злочинців на законослухняних громадян. Тому, при розробці засад діяльності нових місць ув'язнення, цьому аспекту приділено не менше уваги ніж праці засуджених, устрою в'язниць чи матеріальному забезпеченню.

Новий термін «пенітенціарні будинки» дав назву відповідному закону, ухваленому 1779 р., загальновідомому як Пенітенціарний акт. Хоча офіційна його назва Акт про роз'яснення й доповнення законів, що стосуються транспортації та інших видів покарання правопорушників (An act to explain and amend the laws relating to the transportation imprisonment and other punishment of certain offenders) [20]. Він приписував звести коштом парламенту два експериментальні пенітенціарні будинки для утримання осіб, засуджених до транспортації, або тих, кому смертна кара була замінена позбавленням волі у поєднанні з каторжними роботами, та детально регламентував їхній устрій, організаційні та режимні засади [21].

Слід зазначити, що і принципи адміністрування пенітенціарних будинків, і елементи режиму багато у чому були запозичені 3 практики європейських в'язничних робітних i виправних будинків. Це дозволяє зробити висновок, що Пенітенціарний акт 1779 р. акумулював, розвинув і закріпив на загальнодержавному рівні європейський континентальний досвід виправного покарання. Разом з тим, ухвалення акту ознаменувало важливий, можна сказати, поворотний момент в еволюції 
модерної тюрми - централізацію системи відбування покарання i, відповідно, побудову в майбутньому пенітенціарної системи. Як зауважує Н. Деві, Пенітенціарний акт започаткував нову концепцію в'язниці (що поєднувала уже усталений виправний підхід, направлений на тіло правопорушника, та методи духовного та психологічного впливу) як «засади державної політики» $[22,18]$.

Приписи Пенітенціарного акта не були реалізовані, оскільки 17841786 рр. відновлено транспортацію до Австралії. Однак він мав важливе значення для подальшого удосконалення діяльності чинних місць ув'язнення і побудови нових тюрем i виправних будинків, в якості місцевої ініціативи, а не централізованої реформи. У графстві Глостершир 3 ініціативи Дж. О. Пола зведено карний комплекс, що поєднував тюрму для підслідних і підсудних, заклад для неповнолітніх злочинців, пенітенціарій і виправний будинок (Common Gaol, Penitentiary \& House of Correction). 1785 року парламент ухвалив Тюремний акт для Глостера $[23,10-40]$. У ньому йшлося про створення спеціального комітету для підготовки та контролю за будівництвом карних закладів (тюрми та п’яти виправних будинків); а також було визначено вимоги до плану тюрем та пенітенціарних будинків (роздільні місця утримання, одиночні камери, наявність приміщень під лазарет, каплиці тощо). Як бачимо 3 назви й змісту акта, пенітенціарні будинки визначено окремими місцями утримання, поряд з тюрмами та виправними будинками. У них, відповідно до ст. XXXIV, мали утримуватися особи, засуджені до каторжних робіт.
Джорджа О. Пола справедливо називають першим тюремним реформатором, якому на практиці, системно і найбільш повно вдалося реалізувати ідеї Дж. Хенуея, Дж. Говарда, В. Ідена, В. Блекстона й приписи Пенітенціарного акта 1779 р. Як зазначав Р. А. Купер, «Говард описав ідеальну тюрму, а Пол їі побудував» [24, 73-74].

Плани виправних будинків для графства Глостершир розробляв один iз найуспішніших архітекторів Британії В. Блекборн. Упродовж 10 років він спроєктував близько 20 тюрем, працюючи у тісній співпраці 3 Дж. Говардом, який називав архітектора «геніальним містером Блекборном» і додавав, що «лише той здатен втілити його бачення як має виглядати тюрма» [25, 41].

В. Блекборн підходив до архітектурного плану тюрми технологічно, з точки зору їі утилітарного призначення. Він запровадив безліч новаторських рішень щодо покращення вентиляції в'язничних приміщень для запобігання тюремній лихоманці та спрощення нагляду: грати на вікнах замість скла, залізні решітки замість дверей у коридорах корпусів, подвійні дерев'яні та решітчасті двері у камерах, просторі внутрішні двори тощо [26, 181]. Його ідеї використовувалися при плануванні пенітенціаріїв упродовж наступних 100 років. В. Блекборн одним із перших запропонував різні конфігурації розташування в'язничних корпусів відносно центральної адміністративної будівлі: у виді віяла, хрестоподібно, півколом. У графстві Глостершир за планами В.Блекборн зведено виправні будинки у Хорслі, Літледені, Нортличі. 
Але найбільш масштабним став тюремний комплекс (Common Gaol, Penitentiary \& House of Correction) в Глостері, відкритий 1791 р. Він був розрахований на 400 осіб, що розміщувалися у різних корпусах. В одному з них, власне пенітенціарному будинку, утримувалися засуджені до транспортації (як альтернатива безстроковому вигнанню в колонії) та смертної кари (але були помилувані). У пенітенціарному будинку було 32 одиночні камери для чоловіків та 12 - для жінок, у яких засуджені перебували й вдень, і вночі. Але вони могли бачитися 3 іншими ув'язненими під час богослужінь, прогулянок, прийому їжі тощо. По двоє засуджені працювали на механічному колесі, що підіймало воду. Ув'язнених відвідували лише начальник тюрми, лікарі й капелан, які повинні були опікуватися їхнім моральним та фізичним станом. Саме вплив добропорядних джентльменів, бесіди та настанови капелана, у поєднанні 3 усамітненням мали відігравати основну роль у процесі усвідомлення засудженими своєї вини та виправлення. Значне місце серед засобів впливу на злочинця відводилося релігії [9, 101-103].

Певний презирливий статус ув'язнених, як елемент перевиховання, був закріплений у правилах закладу. Зокрема, одягнені вони мали бути в грубу однакову тюремну робу з відмітними знаками (це також полегшувало розшук засуджених у разі втечі). Праця розглядалася скоріше як елемент виснаження злочинця й придушення його волі. Дж. О. Пол вважав, що заняття ремеслом для таких злочинців - це привілей, винагорода. 3 огляду на суворі правила дисципліни, особливої ваги набував нагляд за засудженими з боку персоналу в'язниці та чітке виконання ними своїх обов'язків, недопущення потурання ув'язненим [9, 102103].

Більш детально засади діяльності та правила внутрішнього розпорядку карних установ графства було визначено у збірці General regulations for inspection and controul of all the prisons: together with the rules, orders, and bye laws, for the government of the gaol and penitentiary house, for the county of Glocester 1790 p. [27]. Вона містила детальні структуровані приписи щодо 1) контролю і нагляду за діяльністю місцевих тюрем, будинків корекції та пенітенціарних будинків з боку суддів та магістратів; повноважень і персонального складу тюремних комітетів кожного закладу, інспекцій тюрем та пенітенціарних будинків; 2) суворого одиночного утримання як дисциплінарного заходу; 3) поділу засуджених на категорії (чоловіки, жінки, запеклі злочинці, боржники тощо) та правил утримання.

Окремо було розроблено Загальні правила для тюрем і Правила й приписи для пенітенціарного будинку, що базувалися переважно на приписах Пенітенціарного акта 1779 р., але більш детально регламентували питання управління в'язницями та пенітенціарними будинками. У Загальних правилах для тюрем визначено права та обов'язки, оплату праці управителя в'язниці, майстра, капелана, лікаря, обов'язковий щоденний огляд засуджених, розпорядок дня, харчове забезпечення. Заборонялися азартні ігри, алкоголь, плати, що традиційно стягувалися з новоприбулих злочинців $[27,17-35]$. 
Дж. О. Пол розумів, що якими би досконалими й детальними не були правила в'язниці, ефективність iii діяльності залежатиме все ж від персоналу, особливо управителя. Досвід дореформених англійських тюрем свідчив, що саме начальники тюрем i зловживали владою. Щоб запобігти цьому введено незалежну від очільника посаду капелана, який призначався суддями і був підконтрольний лише їм $[9,127]$. Крім традиційних функцій щодо відправлення культу, навчання, духовних настанов, він також повинен був вічна-віч зустрічатися 3 засудженими, вислуховувати їхні скарги тощо.

Капеланом у Глостері міг бути лише представник англіканської церкви. Він щосереди та щоп'ятниці читав ранішню молитву, а щонеділі, на Різдво й у Страсну П’ятницю відправляв службу; вів щоденник, у якому фіксував свої візити до в'язниці, питання, що виникали 3 огляду на його службові обов'язки, та власні спостереження [27, 22-23].

Режим пенітенціарного будинку регламентовано окремим документом - Підзаконні акти, правила та накази стосовно класифікації, використання та управління засудженими в Пенітенціарному будинку (Bye laws rules, and orders, for classing, employing, and governing the Prisoners Confined in the Penitentiary House) $[27,65-78]$. У ст. 2 розвинуто положення Пенітенціарного акта 1779 р. про поділ засуджених на три класи: упродовж першої третини строку засуджений перебував у першому класі й виконував найтяжчу роботу; далі, за відсутності порушень дисципліни, він переводився до другого класу й був задіяний на менш важких роботах. Засуджені третього класу могли призначатися constables of a division (щось на кшталт старшого відділення) або помічниками з прибирання камер чи наставниками на виробництві (ст. 3). Режим утримання кожного класу міг корегуватися місцевими суддями [27, 66-67].

Якщо характер виробництва вимагав спільної діяльності кількох засуджених, то за ними обов'язково слідкував наглядач (ст. 5). Засуджені до транспортації, що утримувались у пенітенціарному будинку перед відправленням до колоній, перебували також в одиночних камерах. До праці вони могли не залучатися та отримували мінімальну їжу, оскільки кошти на їхнє утримання виділяла держава, а не магістрат (ст. 10).

у правилах Пенітенціарного будинку Глостера набули подальшого розвитку норми про опіку над особами, які звільняються з в'язниці. Так, ст. 27 передбачала, якщо злочинець під час відбування покарання був працьовитим і добре себе поводив, то капелан, управитель або суддя, будучи переконаними в його виправленні, надаватимуть такому засудженому при звільненні документ, який би підтверджував це, та, за рішенням суддів, певну суму грошей. Особам, які звільнялися 3 пенітенціарного будинку, видався цивільний одяг (власний чи будьякий пристойний) і гроші, для того, щоб дістатися до місця проживання (не більше 10 шилінгів). Якщо особа після звільнення влаштовувалася на роботу й через рік надавала письмове підтвердження від роботодавця про свою добру службу та чесну поведінку, що також підтверджував представник місцевої влади, то судді могли виділити їй додаткові кошти. 
B'язничний комплекс у Глостері з-поміж подібних закладів привернув найбільше уваги й вважався зразковим. I хоча виникали проблеми з дотриманням режиму мовчання та дисципліни, складною системою класифікації в'язнів, виконанням обов'язків персоналом, на слуханнях у парламентському комітеті $1811 \mathrm{p}$. Дж. О.Пол зазначив, що тюрма виправдала всі самі оптимістичні його сподівання і навіть більше багато хто після в'язниці став законослухняним громадянином і чесно заробляв собі на життя $[24,90]$. Той факт, що Дж. О. Полу вдалося втілити приписи Пенітенціарного акта 1779 р. щодо заміни транспортації та смертної кари тюремним ув'язненням, надавав пенітенціарному будинку Глостера особливої ваги на загальнодержавному, а не лише локальному рівні $[9,100]$.

3 огляду на успіхи у справі впровадження нових карних закладів у графствах, а також коштовність транспортації, незадовільні умови утримання в халках та високу смертність у них на початку XIX ст. парламентарі та урядовці (не без тиску релігійних товариств) повернулися до питання реформи системи покарань. У 1811 р. скликано парламентський комітет під головуванням Дж. Холфорда, який мав критично оцінити ефективність виконання покарання у виді транспортації та утримання в халках, а також розглянути питання зведення пенітенціарного будинку. В якості модельних закладів обрано: пенітенціарій у Глостері (Дж. О. Пол був одним із доповідачів), виправний будинок в Саутвеллі (у якості експерта виступив його капелан Дж. Т. Бехер) та проєкт Паноптикону Дж. Бентама [28].
У контексті огляду діяльності та засад функціонування пенітенціарного будинку в Глостері у звіті комітету вперше на офіційному рівні ужито термін «система пенітенціарного ув'язнення» (a system of Penitentiary imprisonment), під якою розуміли систему відбування покарання в умовах ізоляції, що передбачає не лише безпечне утримання правопорушника, але і його виправлення $i$ зміну свідомості через усамітнення та релігійні настанови [28, XC-XCI]. Також термін «пенітенціарна система» вжито у працях Дж. Бентама: «пенітенціарну систему Паноптикону» він протиставляв системі халків та транспортації [29].

У травні 1811 р. Комітет Холфорда направив до парламенту висновок, у якому, проаналізувавши умови та строки утримання засуджених до транспортації, члени комітету визначили, що в пріоритеті - побудова достатньо великого пенітенціарного будинку для Лондона та столичного графства Мідлсекс [28, LXXXIX, XCVI]. За основу устрою майбутнього пенітенціарного закладу комітет вирішив узяти кращі елементи режиму утримання в Глостері та Саутвеллі. Пропонувалася прогресивна система відбування покарання і розділення засуджених на класи. Засуджені першого класу, відразу після поміщення до пенітенціарного будинку, повинні були утримуватися в одиночному ув'язнення у найбільш суворих умовах (як це практикувалось у Глостері); для переведених до другого класу встановлювався б режим утримання на зразок того, що був у виправному будинку Саутвелла. Однак, члени комітету, вдавшись до механічного об'єднання, не змогли осягнути суперечності у філософії й 
меті покарання цих двох закладів, що і визначали відмінність у їхніх режимах [9, 140]. У Глостері виправлення мало досягатися через усамітнення та заглиблення в себе і, як наслідок, покаяння, а в Саутвеллі - через працю, соціальну адаптацію в малих групах під контролем адміністрації й формування позитивних навичок.

Результатом роботи Комітету Холфорда стало ухвалення парламентом актів про будівництво в столичному районі Міллбенк пенітенціарного будинку, розрахованого на 600 (300 чоловік і 300 жінок) засуджених до транспортації та злочинців, яким смертну кару замінено тюремним ув'язненням, графства Мідлсекс та Лондона [30, 303-304; 31, XLVIII]. Для інших регіонів планували звести пенітенціарії за типовим планом. Однак у процесі будівництва, що тривало упродовж 1813-1821 рр., збільшено кількість камер і заклад міг вмістити понад 1000 засуджених. 3 огляду на це, його було введено в експлуатацію як загальнонаціональний для Англії, Уельсу та Шотландії General Penitentiary at Millbank. У регіонах відкривали окремі пенітенціарні «сектори» в новозведених або уже діючих виправних будинках, як зокрема Монмутширі в Уельсі.

Інспекторами-наглядачами будівництва призначено Дж. Холфорда, Дж. Т. Бехера та Ч. Лонга [32, 47]. У конкурсі на кращий проєкт пенітенціарного будинку першість дістав художник-кресляр Королівського військового коледжу В. Вільямс. Його проєкт інспектори доручили доопрацювати знаному архітектору Т. Хардвіку, під керівництвом якого і було розпочато будівельні роботи.

Остаточний план пенітенціарного будинку Міллбенк у формі п'ятикутної зірки нагадував більше фортецю, ніж виправний заклад [33, 13]. За архітектурним стилем його радше можемо віднести до «architecture terrible», за яким зведено і лондонську в'язницю Ньюгейт. Такий підхід був продовженням каральної середньовічної пенальної традиції, у якій тюрма - це, перш за все, міцні стіни, грати та кайдани, їі мета - вселяти страх. Так, уже на етапі проєкту був певний дисонанс між «terrible» будівлею, що усім своїм виглядом залякувала, і метою виправлення злочинця, власне задля чого і зводився заклад.

Це був комплекс у виді шести окремих триповерхових пентагонів, розміщених навколо адміністративного корпусу у формі шестикутника, у центрі якого була каплиця. Пенітенціарій займав територію 16 акрів і був оточений кам'яною стіною з масивною брамою у центрі. Кошторис будівництва, визначений Т. Хардвіком, склав $259725 £$ (до цього, найдорожчий виправний будинок в Англії було зведено за $65656 £[34,167])$.

Уже на початку будівництва виникли значні труднощі із закладенням фундаменту будівлі на болотистих грунтах поблизу р. Темзи. Після консультацій 3 провідними столичними інженерами при будівництві в'язниці було застосовано найновіші технології. Звичайно, це суттєво збільшило видатки. У кінці 1813 р. Т. Хардвік зажадав збільшення гонорару, оскільки будівництво потребувало більше зусиль, ніж він планував, а коли отримав відмову, звільнився. Комітет найняв менш відомого, але достатньо досвідченого Дж. Харві. У 1815 р., коли у вже зведених корпусах через просідання 
фундаменту пішли тріщини, його замінили Р.Смірком, який разом 3 інженером Дж. Ренні, укріпив фундамент бетоном (ця технологія в Англії при зведенні публічних будівель була застосована вперше у Міллбенк) і 1821 р. завершив будівництво [12, 44-46].

Усі ці перипетії зі зміною архітекторів, інженерно-будівельні складнощі ілюструють наскільки проблематичною 3 самого початку була реалізація такого масштабного проєкту. Видатки постійно зростали й інспектори повсякчас зверталися до парламенту за додатковими асигнуваннями. I хоча в доброчесності інспекторів не було підстав сумніватися, ніхто не міг передбачити, що загальна сума витрат зросте вдвічі й у підсумку складе астрономічну для тих часів суму $458000 £$. Як саркастично зазначали С. Вебб та Б. Вебб, це був найкоштовніший проєкт у світі, звісно, після єгипетських пірамід. 3 огляду на вартість, строки будівництва та зовнішній вигляд комплексу, який називали «пам'ятником потворності» («monument of ugliness»), жителі столиці були не в захваті від нового карного закладу, розміщеного неподалік англійського парламенту [32, 48].

Заощадити на заміні транспортації тюремним ув'язненням не вдалося. І слабою втіхою було те, що при незначному перегляді проєкту у Мідллбенк можна було розмістити майже вдвічі більше ув'язнених ніж це планувалося. Значні витрати були зумовлені, по-перше, масштабністю проєкту пенітенціарію (до цього виправні будинки зводили максимум на 100-200 осіб), по-друге, складним архітектурно-інженерним рішенням. Міллбенк мав стати в'язницею ново- го типу, в якій план, організація простору, розташування камер, майстерень, сходів тощо визначалися вимогами режиму, безпеки та санітарногігієнічними нормами.

Функціональне призначення i в'язничний режим стали визначальними для просторових рішень. I будь-які недоліки, допущені при початковому планування архітекторами чи інженерами, у подальшому неодмінно позначалися б на режимі й ув'язнених. Так, будівництво в'язниць на березі річки, як «заповідав» Дж. Говард, на практиці, у тому числі в Міллбенк, призвело до підтоплення фундаменту й підвищенні вогкості приміщень. Складно спроєктовані корпуси Міллбенк більше нагадували лабіринт. Численні переходи, гвинтові сходи, безліч воріт і дверей ставали справжнім випробуванням для персоналу в'язниці. Один із наглядачів після довгих років служби зізнавався, що все ще не міг без проблем знайти вихід і через це постійно носив з собою крейду, якою позначав вірну дорогу [12, 33].

27 червня 1816 р. у першому зі зведених пентагонів розміщено 36 жінок, переведених 3 в'язниці Ньюгейт. Початково він призначався для чоловіків, але у цей період у в'язницях графства перебувала критична маса жінок, засуджених до транспортації: уряд не готовий був їх відправляти до Австралії, а в халках жінок не утримували. По мірі того, як здавали в експлуатацію наступні пентагони, у них розміщували засуджених. У 1819 р. загальна кількість ув'язнених пенітенціарного будинку склала 325 осіб (126 чоловіків і 199 жінок), у 1820 р. - 551 особа (відповідно, 274 і 277); 
станом на червень 1823 р. у Міллбенк утримувалося 878 осіб [35, 33-34]. Слід зазначити, що на повну потужність (1200 місць) заклад ніколи не працював.

Загальні засади управління пенітенціарієм Міллбенк грунтувалися на приписах, започаткованих ще Пенітенціарним актом 1779 р., що були доповнені з огляду на практику функціонування виправних будинків у Глостері та Саутвеллі. Функція загального керівництва, нагляду та контролю покладалася на спеціальний комітет. Його склад було сформовано принцом-регентом у лютому 1816 р. Членами комітету стали поважні та впливові політики й релігійні діячі, а також колишні інспектори (Дж. Холфорд, Ч. Лонг) та практики-тюрмознавці (Дж. Т. Бехер i В.М. Піт). Очолив комітет спікер парламенту. Таке представництво наглядового органу безумовно надавало ваги пенітенціарному починанню. Комітет звітував про свою діяльність перед парламентом та Судом королівської лави.

Членами комітету розроблено Правила i приписи для управління Головним пенітенціарієм [36]. Відповідно до яких, комітет повинен був збиратися не рідше ніж раз на місяць (на практиці в перші роки засідання відбувалися набагато частіше [9, 146]) і призначати принаймні одного візитера для контролю за діяльністю пенітенціарного будинку. Він повинен був відвідувати засуджених і спілкуватися 3 ними, перевіряти журнали обліку та звітності. Комітет визначав режимні засади закладу, види в'язничних робіт, призначав управителя пенітенціарного будинку, капелана, матрону, лікаря, економа та майстра виробництва.
3 самого початку члени комітету, особливо Дж. Холфорд, який перебував у Міллбенк майже постійно, сконцентрували у своїх руках значні управлінські повноваження. Перший начальник закладу скаржився, що члени комітету постійно втручалися в його діяльність, зокрема давали розпорядження та вказівки наглядачам, не ставлячи його до відома. Вони заохочували усілякі скарги, навіть систему шпіонажу, бажаючи за будьяку ціну виявити зловживання адміністрації.

3 іншого боку, пенітенціарій Міллбенк, на переконання А. Гріффітса, був для інспекторіввізитерів такою собі «грою у благодійність» i шляхетним заняттям у вільний час. Вони полюбляли приводити туди своїх друзів, щоб ті спостерігали за процесом «виправлення» $[12,58-59,68]$.

Тотальний контроль 3 боку комітету призводив до нівелювання авторитету управителя пенітенціарного будинку. Фактично, він ділив повноваження 3 капеланом та матроною. Таким чином комітет намагався встановити запобіжники й унеможливити узурпацію влади. I хоча повноваження управителя були описані в 30 пунктах Правил, поширювалися вони переважно на засуджених, а не на персонал. Коротко їх суть можна сформулювати як забезпечення утримання під наглядом та підтримка дисципліни [9, 147], за порушення якої він міг накладати незначні дисциплінарні стягнення (більш суворі заходи впливу - лише після узгодженням з комітетом). Щодо урядників, то управитель міг відсторонювати їх від виконання обов'язків (окрім посадовців, що їх призначав комітет), але не звільня- 
ти. Він не відповідав ні за виробництво (з огляду на це, не отримував додаткових прибутків 3 доходів від виробництва, а лише фіксовану платню - $600 £$ на рік), ні за виправлення засуджених, оскільки це належало до компетенції капелана. Управитель повинен був проживати 3 сім'єю на території пенітенціарного будинку i, по можливості, бути постійно присутнім на службі. Якщо він тимчасово залишав заклад, то робив запис про це й офіційно передавав свої повноваження майстру, який його заміщав.

Однією 3 основних проблем в'язничної системи на початку XIX ст. була нестача кваліфікованого персоналу. I якщо для роботи у в'язниці загалом було складно найняти чесних і порядних службовців, то в пенітенціарному закладі й поготів. У першу чергу це стосувалося управителя. Члени комітету принципово не хотіли бачити на цій посаді людину 3 досвідом роботи у в'язниці. Така особа, на їхню думку, ipso facto не могла бути добропорядною і скоріш за все зловживала б владою $[9,152]$. Першим управителем Міллбенк 10 квітня 1816 р. призначено лондонського адвоката, що на той час працював клерком, 44-літнього Дж. Ширмена (попередньо комітет направив його оглянути декілька місць ув'язнення, набути, так би мовити, «практичного досвіду») [12, 49]. Однак за кілька місяців він звільнився. Упродовж наступних шести років управителі змінювалися тричі. Виявилося, що лише добропорядності було не достатньо, для того, щоб ефективно управляти пенітенціарієм. Більшменш тривалий час цю посаду займав капітан Б. Чепмен. Після посилення у Міллбенк репресивної скла- дової режиму утримання посада управителя була поєднана з посадою капелана.

Першим капеланом Міллбенк 1816 р. став С. Беннетт $[12,50]$. Цю посаду міг займати лише представник англіканської церкви, кандидатуру якого затвердив єпископ. Капелан Міллбенк мав особливий статус серед тюремних службовців, на кшталт пенітенціарного будинку в Глостері, i був підзвітний лише комітету. Таким чином, уже в Правилах Міллбенк закладено перманентний конфлікт в системі взаємовідносин: управитель-капелан $[9,162-$ 163]. Саме останній повинен був сповіщати комітет про будь-які зловживання адміністрації. У разі виникнення у матрони труднощів, приписувалося звернутися або до управителя, або до капелана $[36,18]$.

Як влучно зазначає Ш. МакКонвіл, у цьому «конфлікті», з огляду на сферу повноважень (у питаннях підвладних управителю, зокрема режиму та безпеки, виникало більше проблем, ніж у діяльності капелана), управитель завжди знаходився в незавидному становищі й мало чув схвального від комітету. Натомість у капелана - «інструмента пенітенціарної терапії» майже не було шансів зазнати поразки, оскільки результати його роботи важко було оцінити за чіткими критеріями. Члени комітету постійно робили акцент на «вагомій християнській меті закладу» і тих сподіваннях, які вони покладають на релігійний вплив у процесі виправлення $[9,162]$.

До обов'язків капелана, крім традиційної служби, читання молитов, відправлення обрядів, розповсюдження релігійної літератури, пастирської опіки як засуджених, 
так і персоналу в'язниці, належало також: навчання неписемних засуджених, цензура листування, зібрання інформації про моральний стан ув'язнених і фіксація їі в спеціальних журналах (character book). В останніх зазначалися дані про кожного засудженого, особливості його характеру, схильності, прогрес на шляху виправлення тощо.

Представників інших віросповідань могли відвідувати за дозволом капелана їхні духівники. Управитель, матрона, а також старші наглядачі кожного корпусу повинні були негайно повідомляти капелана про будь-які порушення норм моралі та подавати списки засуджених, відсутніх на богослужінні. Заробітна плата капелана складала $400 £$ на рік [36, 12-14, 18].

Правила пенітенціарного будинку передбачали й інші штатні посади тюремних службовців, зокрема: матрони, яка була заступником очільника закладу щодо управління жіночим відділенням; лікарів; майстра, що відповідав за організацію виробництва, навчання ремеслам, збут продукції, вів облік трудової зайнятості та заробітків засуджених; економа, який забезпечував засуджених продовольством та одягом. Для кожного пентагону призначався старший (taskmasters), у підпорядкування якого знаходилися наглядачі (turnkeys). Правила вимагали, щоб вони свої обов'язки виконували неухильно, були принциповими, але гуманними щодо засуджених. Жінкинаглядачки підпоряковувалися матроні. Допомогу наглядачам щодо підтримання дисципліни надавали «охоронці» (wardmen, wardwomen) 3 числа засуджених другого класу, найбільш благонадійних та поряд- них. Також такі особи могли призначатися інструкторами на виробництві [12, 55].

Як бачимо, в пенітенціарному будинку Міллбенк було створену розгалужену адміністративноуправлінську вертикаль, з достатньо чітко визначеними функціональними обов'язками посадовців, розроблено форми звітності тощо. Ш. МакКонвіл звертає увагу, що у той час, коли апарат міністерства внутрішніх справ нараховував лише кілька клерків, пенітенціарій був фактично новим державним департаментом. Хоча його службовці й не мали особливого адміністративного досвіду. Окрім того суперечності в управлінських методах, цілях пенітенціарія й засобах їх досягнення впливали на ефективність роботи $[9,151]$.

Режим утримання у Міллбенк було диференційовано: засуджені першого або випробувального класу й вдень, і вночі утримувалися в одиночних камерах; після відбуття половини строку, за відсутності стягнень, вони переводилися до другого класу, що передбачав утримання в одиночній камері лише ввечері та вночі, а в день - роботу в загальних майстернях.

За не виконання наказів, неповагу до адміністрації, неробство та відсутність на богослужіннях без поважної причини засудженим загрожувало поміщення у камеру, де вони б перебували у суцільній пітьмі на «хлібі й воді». Більш суворі стягнення, зокрема пониження в класі, могли накладатися лише комітетом. Натомість за хорошу поведінку та старанну працю ув'язненні могли бути представлені державним секретарем до помилування волею монарха. У якості заохочення, понад зароб- 
лених коштів, після звільнення комітет міг надавати додаткову суму в розмірі не більше $3 £$.

Окрім особливого режиму утримання, ще однією складовою виправного покарання, за задумом реформаторів, мала стати праця засуджених. Значні зусилля як комітету, так і адміністрації були спрямовані на організацію тюремних робіт. Засуджені, які мали певні навички, повинні були навчати ремесел інших. Однак, 1822 р. Дж. Холфорд змушений був визнати, що майже усі починання щодо започаткування виробництва виявилися невдалими й зайнятість засуджених обмежувалася ткацтвом та пошиттям одягу досить низької якості, оскільки не було хороших закрійників $[12,59 ; 35,73-74]$.

Невдачі з організацією виробництва були досить прогнозовані, оскільки у пенітенціарному будинку в Глостері, режим якого було перейнято щодо утримання засуджених першого класу, праця не була значимим елементом. Уся надія залишалася на третю складову - релігійний вплив. 3 роками, в процесі трансформації режиму утримання у бік його посилення в другій половині 30-х років XIX ст. й остаточного нівелювання біхевіористичного саутвеллівського підходу, побожність, регулярне читання молитов, бесіди з капеланом, навчальні релігійні програми стали настільки всеохоплюючими (особливо, коли капелан зайняв і посаду управителя), що вимоги майже фанатичної релігійності поширювалися не лише на засуджених, але й на персонал. Службовці, що не відповідали їм, були звільнені. Інші ж, побоюючись звинувачень зі сторони колег або засуджених, лицемірили, демонструючи на позір «свою релігійність», носили постійно з собою Біблії тощо $[9,142,163,167]$. Пенітенціарій, за такого, підходу більше нагадував монастир, ніж в'язницю $[12,195]$.

Звичайно, до удаваної побожності більше вдавалися засуджені, маючи надії на різноманітні преференції. Але найбільш зухвалі злочинці часто дозволяли собі знущатися й насміхатися з наставників з числа засуджених другого класу, які читали їм молитви. Вони заявляли, що «немає такого закону, щоб примусити їх читати «Отче наш», якщо вони того не бажають». Засуджений Дж. Веллс написав на своїй тюремній чашці: "Yor order is for me to go to chapel, but mine is that I'll go to Hell first» (що у вільному перекладі може звучати як: "Ваш наказ іти до церкви, але я скоріше піду до пекла»). У відповідь на зауваження Дж. Веллс лише розсміявся управителю в лице [12, 195-196].

Присутність капелана у в'язниці не гарантувала автоматичної поваги до нього. I Міллбенк, незважаючи на особливі повноваження тюремного священника, не був виключенням. Засуджені пенітенціарію навіть планували вбивство капелана під час богослужіння $[37,170]$. I це при тому, що пенітенціарний будинок був (або позиціонувався) як зразковопоказовий заклад. у Міллбенк міністерство внутрішніх справ направляло лише таких засуджених до транспортації, які «мали потенціал» виправитися в майбутньому за відповідного виховного впливу [9, 138-139].

Штучне створення поблажливих умов для відбування покарання в експериментальному пенітенціар- 
ному будинку викликало справедливі нарікання. Один із послідовних критиків такого «виправного режиму» депутат від Ессекса Ч. Вестер назвав Міллбенк «образою доброчесних трудящих», закладом, який суперечить здоровому глузду. Він писав: «Пенітенціарний будинок Міллбенк породжує оманливі надії і хай би експеримент ним би й обмежився» [38, 101, 113]. Через розкішні, як здавалося громадськості та опонентам Дж. Холфорда, умови утримання пенітенціарій часто був мішенню для нападок і жартів [12, 75]. Міллбенк називали «відкормчим будинком Холфорда» [39, 114] (не тому, що заклад приносив зиск чи був кормлінням фундатора, а в тому сенсі, що засуджені могли там добре від'їстися). 3 певною іронією критики пропонували у Міллбенк залишити мінімальну кількість наглядачів, оскільки - хто ж захоче втікати з такого місця $[12,75]$.

Парламент, i так виділивши вдвічі більшу суму на будівництво закладу, не готовий був кожного року знову й знову асигнувати значні кошти на підтримання діяльності пенітенціарного будинку. 1821 року депутати, погрожуючи наступного року загалом не надати фінансування, змусили комітет вдвічі урізати видатки на тюрму $[12,77]$. У результаті чого адміністрація почала суттєво економити на харчуванні, що спочатку призвело до виступів засуджених, а 1822 р. - i до масових захворювань. На початку 1823 р. у значної кількості ув'язнених Міллбенк діагностували цингу, а пізніше й дизентерію. Намагаючись запобігти паніці як у самому закладі, так і в місті, лікарі спершу приховували масштаби епідемії і не вводи- ли карантин. Як наслідок, незабаром майже у половини засуджених спостерігалися відповідні клінічні симптоми, а часто, на додаток, ще й нервові розлади $[12,82]$.

У літературі нерідко зазначають, що причиною епідемії $\mathrm{y}$ Міллбенк стали міазми з Темзи, нездорова болотяна місцина, вологість тощо [40, 344]. Спокуса саме на це списати погіршення стану здоров'я засуджених була й у членів комітету. Однак лікарі спростували цю тезу, оскільки до 1822 р., коли було урізано норми харчування, подібних симптомів у засуджених не спостерігали; жоден 3 представників адміністрації та ув'язнених, які працювали на кухні, не захворів; стіни камер під час детального огляду виявилися сухими [12, 74-75].

У березні 1823 р. запрошені для боротьби з епідемією провідні лікарі Лондона П. М. Роже та П. М Лайтем рекомендували покращити харчування і ввести у щоденний раціон кожного засудженого чотири унції м'яса й три апельсини (на сніданок, обід і вечерю). У журналі управителя міститься запис, що він відрядив економа на Темз-стріт зарезервувати апельсинів на тиждень [12, 70]. Спроба змінити ситуацію покращенням дієти не дала особливих результатів. У червні 1823 р. хворих нараховувалося більше 400 осіб 3 800 засуджених (30 з них померло) $[12,82]$.

Комітет ухвалив рішення перевести усіх ув'язнених в інші заклади, а пенітенціарний будинок дезінфікувати. Але для цього потрібен був відповідний акт парламенту. Згідно 3 ним, засуджені чоловіки були розміщені в халках, а жінки - в лікарні в Ріджентс-парку. Однак наразі стояло 
питання, що ж робити далі з засудженими, оскільки повертати до Міллбенк їх не збиралися.

За цих умов уперше вдалися до масового помилування, зокрема усіх жінок-засуджених пенітенціарного будинку. Клерки міністерства внутрішніх справ щодо кожної особи 3'ясовували, чи $\epsilon$ у неї родичі чи близькі, які готові ï прийняти. Звільнити декілька сотень чоловіківкаторжан уряд не наважився, тому було вирішено, що вони продовжать відбувати покарання у плавучих тюрмах $[12,83-85,109]$.

Помилування, до якого через епідемію вдалися члени комітету та керівництво закладу, після зазначених подій стало загальновживаною практикою: у 1818 р., при наповненості закладу 223 особи, помилувано було лише трьох засуджених, а 1836 р., при наповненості 400 осіб, $178[9,144]$. Це стало одним із ефективних стимулів для засуджених. Однак з посиленням режиму утримання у кінці 30-х років від цієї практики відмовилися.

Після подолання епідемії і розслідування інциденту парламентською комісією у Міллбенк було модернізовано системи вентиляції та каналізації, а до Правил пенітенціарного будинку внесено поправки, окремі положення розширено та деталізовано, але суттєвих змін не відбулося [42]. Члени комітету та адміністрація не полишили реформаторсько-гуманістичних намірів і все ще сподівалися на успіхи у справі виправлення злочинців. У Міллбенк поміщали засуджених, які найбільш для цього підходили: неповнолітніх; засуджених вперше; злочинців, які мали сталі соціальні зв'язки, родину, розважливий характер тощо.
3 огляду на ріст злочинності в Об'єднаному Королівстві в 30-х роках XIX ст. і відсутність видимих результатів ефективності ліберального підходу до відбування покарання (саме до такого висновку дійшла парламентська комісія, що розслідувала стан справ у закладі $[12,179-$ 180]), оновлений комітет пенітенціарного будинку був вимушений вдатися до зміни режиму. Спільне утримання засуджених другого класу було визнано неефективним. Вважали, що воно лише нівелювало той виправний ефект, який вдавалося досягнути завдяки суворій ізоляції. Вирішено було подовжити період одиночного утримання, але скоротити загальний строк ув'язнення [12, 193]. Скасовано помилування та виплати засудженим частини прибутку від в'язничної праці, яку так і не вдалося ефективно налагодити. Разом 3 тим, було збільшено час релігійного навчання та відновлено тілесні покарання $[9,164-165 ; 40$, 344].

Бажаючи виправляти засуджених, тюремні реформатори не готові були остаточно відмовитися від каральних практик. Через це, як вважає Ш. Грасс, пенітенціарій Міллбенк упродовж двох десятиліть не міг послідовно ні виправляти, ні карати $[43,25]$, поступово перетворюючись на звичайну каральну інституцію, сховану від очей громадськості. Журналіст Times 3 жалем констатував, що Міллбенк став «таємним трибуналом, гіршим навіть за французьку Бастилію» $[43,26]$.

Як бачимо, у пенітенціарії Міллбенк спроба об'єднати два підходи до режиму утримання та виправного впливу: саутвелівський і глостерський завершилися невдачею 
і перемогою останнього. Значну роль у цьому відіграли нові члени наглядового комітету Міллбенк В. Кроуфорд та В. Рассел, що ініціювали зміни в Правилах. Саме ці тюремні реформатори та їхні погляд на виправне покарання й в'язничний режим, з огляду на досвід організації американських пенітенціарних закладів, який вони вивчали, і стали визначальними при реформуванні британських в'язниць і становленні європейських пенітенціарних систем у наступні півстоліття.

Висновки. Враховуючи зазначене, можемо дійти висновку, що першість у справі формування пенітенціарної доктрини відбування покарання та реалізації її на практиці, зокрема у пенітенціарному будинку для священнослужителів та монахів у Корнето, належить канонічному праву та папському законодавству XVII ст. Саме у ньому було запроваджено новаторські елементи в'язничного режиму: ізоляція й усамітнення (утримання в одиночних камерах), сувора дисципліна, релігійні настанови та молитви задля спокутування гріха та каяття. Цей досвід, а також практики в'язничних робітних будинків, було використано при розробці засад діяльності виправних тюрем для неповнолітніх та жінок у Римі при Апостольському хоспісі Св. Михайла.

У контексті реформи системи покарання й заміни транспортації тюремним ув'язненням у Британії наприкінці 70-х років XVIII ст. термін «будинки каторжної праці» замінено на «пенітенціарні будинки», а метою утримання у них визначено виправлення злочинців. Така новація була зумовлена сумнівами законотворців чи варто залишати в межах країни, спершу у карних закладах, а після відбування строку ув'язнення загалом в громаді, запеклих злочинців. Тому реформатори зробили акцент на виправному впливі під час ув'язнення, у результаті якого, як вони сподівалися, колишні злочинці стануть доброчесними громадянами.

I щодо назви, i щодо засад діяльності та режиму відбування покарання, регламентованих Пенітенціарним актом 1779 р., вбачаємо певну наступність пенітенціарних будинків і континентальних виправних та в'язничних робітних будинків. Пенітенціарний акт 1779 р. акумулював, розвинув і закріпив на загальнодержавному рівні європейський досвід виправного покарання і започаткував новий етап еволюції модерної тюрми - централізацію системи відбування покарання i, відповідно, формування пенітенціарної системи.

Приписи Пенітенціарного акту 1779 р. щодо заміни транспортації позбавленням волі в Британії реалізовано у процесі локальної тюремної реформи. Перший пенітенціарний будинок відкрито у карному комплексі в Глостері 3 ініціативи Дж. О. Пола, який не лише втілив теоретичну модель в'язниці нового типу, але й пішов далі на шляху формування та практичної реалізації концепту виправного покарання, заснованого на суворому одиночному утриманні та релігійному впливі. Праця за цього підходу не була основним елементом виправного впливу, а лише засобом виснаження (якщо це робота на механічному колесі) чи заохоченням або нагородою (якщо це заняття ремеслом). Таким чином, ув'язнення у пенітенціарному будинку в Глостері вже не було по 
суті «покаранням у виді каторжних робіт», як це передбачав Пенітенціарний акт $1779 \mathrm{p}$.

У якості новацій у тюремному комплексі в Глостері слід виокремити: чітку нормативну регламентацію діяльності у збірці правил, диференційованих щодо різних категорій ув'язнених; певні вимоги професійного характеру при підборі персоналу; впровадження посади капелана як незалежного від адміністрації закладу тюремного службовця, підконтрольного тюремному комітету i суддям; поділ ув'язнених пенітенціарного будинку на класи, у чому вбачаємо начала прогресивної системи відбування покарання. Режимні та організаційні засади пенітенціарію в Глостері, разом із моделлю відбування покарання у виправному будинку в Саутвелі, стали взірцевими для фундації загальнодержавного пенітенціарного будинку в Міллбенк, підпорядкованого центральній владі.

На початку XIX ст. у Великій Британії на офіційному рівні утвердився термін «система пенітенціарного ув'язнення», що позначав комплекс заходів щодо 1) відбування покарання у виді позбавлення волі в спеціальних закладах (пенітенціарних будинках) в безпечних, гуманних умовах, а також 2) виправлення i зміни свідомості засуджених через усамітнення та релігійні настанови. Відповідно до цього, в країні вперше було реалізовано масштабний проєкт загальнонаціонального пенітенціарного будинку - General Penitentiary at Millbank як альтернативного місця відбування покарання для осіб, засуджених до транспортації. У пенітенціарії Міллбенк сформовано управлінську вертикаль, розгалужений штат службовців, запроваджено форми обліку та звітності. Ключовим штатним службовцем, «інструментом пенітенціарної терапії», став капелан, повноваження якого еволюціонували від періодичного відправлення служби та бесід 3 ув'язненими до керівництва пенітенціарним будинком. Щодо ефективності виправного режиму першого загальнонаціонального пенітенціарного будинку Міллбенк, що передбачав механічне поєднання двох моделей: суворого одиночного утримання щодо засуджених першого класу та спільних робіт та розділення на ніч в одиночних камерах засуджених другого класу, слід зазначити, що воно виявилося неефективним, що і зумовило відхід від гуманістичних засад, посилення режиму утримання та повернення каральних практик.

\section{Список використаних джерел}

1. Ives, G. (1914). A History of Penal Methods. London. Reprinted New Jersey, 1970.

2. Ignatieff, Michael (1981). State, Civil Society, and Total Institutions: A Critique of Recent Social Histories of Punishment. Crime and Justice, 3, 153-192.

3. Rusche, Georg (1933) Arbeitsmarkt und Strafvollzug. Gedanken zur Soziologie der Strafjustiz. Zeitschrift für Sozialforschung, Volume 2, Issue 1, 63-78. https://doi.org/10.5840/zfs193321115

4. Rusche, George, Kirchheimer, Otto (1939). Punishment and Social Structure. New York: Columbia University Press. 
5. Spierenburg, Pieter (2007). The Prison Experience: Disciplinary Institutions and Their Inmates in Early Modern Europe. Amsterdam University Press.

6. Willis, J. (2005). Transportation versus Imprisonment in Eighteenth- and Nineteenth-Century Britain: Penal Power, Liberty, and the State. Law \& Society Review, 39 (1), 171-210. https://doi.org/10.1111/j.0023-9216.2005.00080.x

7. Gibson, Mary (2019). Italian Prisons in the Age of Positivism, 1861-1914. Bloomsbury Publishing.

8. Ignatieff, Michael (1978). A Just Measure of Pain: The Penitentiary in the Industrial Revolution, 1750-1850. New York: Pantheon Books.

9. McConville, S. (2015). A History of English Prison Administration: 1750-1877. Routledge.

10. Throness, L. (2008). A Protestant Purgatory: Theological Origins of the Penitentiary Act, 1779. Aldershot: Ashgate Publishing, Ltd.

11. Benedetti, Roberto (2012). Dalla galera all'Ergastolo. Storia del carcere per ecclesiastici criminali. Ricerche di storia sociale e religiosa, 81, 15-69.

H.S. King.

12. Griffiths, A. (1875). Memorials of Millbank, and Chapters in Prison History.

13. Beltrani-Scalia, Martino (1867). Sul governo e sulla riforma delle carceri in Italia. Torino: G. Favale

14. Ferrante, L. (1983). L'ONORE RITROVATO. DONNE NELLA CASA DEL SOCCORSO DI S. PAOLO A BOLOGNA (SEC. XVI-XVII). Quaderni Storici, 18 (53(2)), 499-527. Retrieved April 19, 2021, from http://www.jstor.org/stable/43777166

15. Monticelli, Chiara Lucrezio (2007). La nascita del carcere femminile a Roma tra XVIII e XIX secolo. Studi storici, 2, 447-476. https://doi.org/10.7375/71646

16. Torres, J. M. (1990). El término 'ergastulum' en la primera literatura monástica (ss. IV-V). Antigüedad y Cristianismo, (7), 287-290.

17. Devereaux, S. (1999). The Making of the Penitentiary Act, 1775-1779. The Historical Journal, 42 (2), 405-433.

18. Crump, John (2014). How influential were the reformers of the eighteenth century to the making of the Penitentiary Act and how important was this Act in punishing offenders in the eighteenth century? (PhD thesis). Aberystwyth University.

19. Du Cane, Edmund (1885). The Punishment and Prevention of Crime. London: Macmillan and Company.

20. The Statutes at Large from the Magna Charta, to the End of the Eleventh Parliament of Great Britain, Anno 1761 [continued to 1806]. By Danby Pickering, T. 32. 1778, 417-445.

21. Див. детальніше: Sokalska, O. (2020). British prison projects: the Hard Labour Bill and the Penitentiary Act. Law Review of Kyiv University of Law, 1, 74-80. https://doi.org/10.36695/2219-5521.1.2020.13

22. Davie, Neil (2016). The Penitentiary Ten: The Transformation of the English Prison, 1770-1850, Oxford, Bardwell Press.

23. The Statutes at Large from the Magna Charta, to the End of the Eleventh Parliament of Great Britain, Anno 1761 [continued to 1806]. By Danby Pickering, T. 35. 1786.

24. Cooper, Robert Alan (1976). Ideas and their Execution: English Prison Reform. Eighteenth-Century Studies, 10 (1), 73-93 https://doi.org/10.2307/2737818

25. Brodie, Allan, Croom, Jane (2002). English Prisons: an Architectural History. English Heritage.

26. Jewkes, Y., Johnston, H. (2007). The evolution of prison architecture. In: Jewkes, Y. Handbook on Prisons, Portland: Cullompton. 
27. General regulations for inspection and controul of all the prisons : together with the rules, orders, and bye laws, for the government of the gaol and penitentiary house, for the county of Glocester [sic]. By Paul, George Onesiphorus. Second edition. Glocester. 1790.

28. First Report from the Committee on the Laws Relating to Penitentiary Houses. Parliamentary Debates: Official Report. Vol. 20. 1812.

29. Sokalska, O. (2020). Jeremy Bentham's Penitentiary System: The Unrealized Project of the Ideal Prison. Issues of crime prevention, 40, 132-146. https://doi.org/10.31359/2079-6242-2020-40-132

30. A Collection of Statutes Connected with the General Administration of the Law: Arranged According to the Order of Subjects. Vol. 6. London, 1836.

31. List of public acts Passed in the Sixth Session of the Fourth Parliament of the United Kingdom of Great Britain and Ireland 52 Geo III A.D. 1812, XLVIII

32. Webb, S., Webb, B. (1922). English Prisons under Local Government. London: Longmans, Green.

33. Vessella, L. (2017). Open Prison Architecture: Design Criteria for a New Prison Typology. WIT Press.

34. Chalklin, C. W. (1998). English Counties and Public Building, 1650-1830. London.

35. Holford, G. (1828). An Account of the General Penitentiary at Millbank; Containing a Statement of the Circumstances which Led to Its Erection, a Description of the Building, Etc., to which is Added an Appendix, on the Form and Construction of Prisons. London, Rivington.

36. Rules and regulations to be observed and enforced for the Government of the General Penitentiary, Milbank. Accounts and Papers of the House of Commons. Vol. 12. Great Britain. Parliament. House of Commons. 1820.

37. Griffith, Lee (1993). The Fall of the Prison: Biblical Perspectives on Prison Abolition. Michigan, Wm. B. Eerdmans Publishing.

38. Western, Charles Callis (1821). Remarks Upon Prison Discipline. In A Letter Addressed to the Lord Lieutenant and Magistrates of the County of Essex. London. C. H. Reynell.

39. Selection of Reports and Papers of the House of Commons: Prisons, Vol. 52. 1836. University.

40. Semple, J. (1990). Jeremy Bentham's Panopticon Prison. (Ph.D. thesis). London

41. Report of the physicians on the state of the General Penitentiary at Milbank 5th April 1823. In Selection of Reports and Papers of the House of Commons: Prisons, Vol. 52. 1836, 5.

42. Rules and Regulations of the General Penitentiary: Millbank, July 1825.

43. Grass, Sean (2014). The Self in the Cell: Narrating the Victorian Prisoner. Routledge.

o. Sokalska, PhD in Law, Associate Professor

e-mail:co2001@ukr.net; ORCID:0000-0001-8737-0829

\section{The first penitentiary houses in Europe: from religious charity to state criminal policy}

The author has analyzed the process of development of penitentiary institutions: from the establishment in the 17th century penitential houses for delinquents and penitentiary houses for priests and monks as an alternative to galleys to the "penitentiary experiment" in Britain in the late 18th and early 19th centuries. 
This article identifies the statutory regulations, the principles of administration, and the features of the prison regime of the Corneto Penitentiary, the Penitentiary at Gloucester, and the General Penitentiary at Millbank. The author has observed how the requirements of the Penitentiary Act of 1779 were transformed as the "penitentiary experiment" was put into practice.

Both terminologically and in the principles of organization and regime of punishment established by the Penitentiary Act of 1779, English penitentiary houses developed continental penal practices of correctional punishment. The fact that penitentiaries, according to the Penitentiary Act of 1779, were institutions founded on the initiative of the central government and was to be subject to it, indicates the beginning of a new era in the development of the modern prison.

Keywords: Corneto Penitentiary; the Penitentiary Act 1779; transportation; hard labour; Common Gaol, Penitentiary \& House of Correction; penitentiary system; General Penitentiary at Millbank. 